\title{
Coronary artery aneurysms involving all the three coronaries: a rare entity
}

\author{
Pritesh Parekh, Navin Agrawal, Mahesh Vinchurkar, Apurva Vasavada
}

Department of Cardiovascular Sciences Care Hospital, Surat, Gujarat, India

\section{Correspondence to} Dr Navin Agrawal,

drnavinagrawal@gmail.com, dr_navinagrawal@yahoo.co.in

Accepted 27 February 2014

\section{DESCRIPTION}

Coronary artery aneurysm (CAA) is defined as dilation exceeding the reference vessel diameter by $50 \%$, while they are termed giant if their diameter exceeds the reference vessel diameter by four times or if the diameter is more than $8 \mathrm{~mm} .{ }^{1}$ It is uncommon to see aneurysmal involvement of all the three coronary arteries simultaneously.

We present a case of an elderly man who presented with symptoms of class III angina for which he underwent a diagnostic angiogram, which revealed the presence of an atherosclerotic aneurysm involving all the three coronary arteries with one of them being of a giant size of $16 \times 34 \mathrm{~mm}$. The patient had critical triple vessel disease for which he underwent coronary artery bypass grafting along with ligation and repair of the aneurysm of the left anterior descending (figures 1-3, videos 1-3).

Atherosclerosis accounts for the vast majority of CAAs in adults. Other causes include Kawasaki disease, Takayasu's arteritis, poly arteritis nodosa, lupus erythematosus, connective tissue disorders, congenital defects, infections (such as narcotic emboli, syphilis and Lyme disease), trauma, dissection and cocaine abuse, and may be either iatrogenic or idiopathic.

There is no definite recommendation for the appropriate indication and timing of management of atherosclerotic aneurysms of coronary arteries, neither is there a definite modality of choice of treatment although surgical ligation or covered

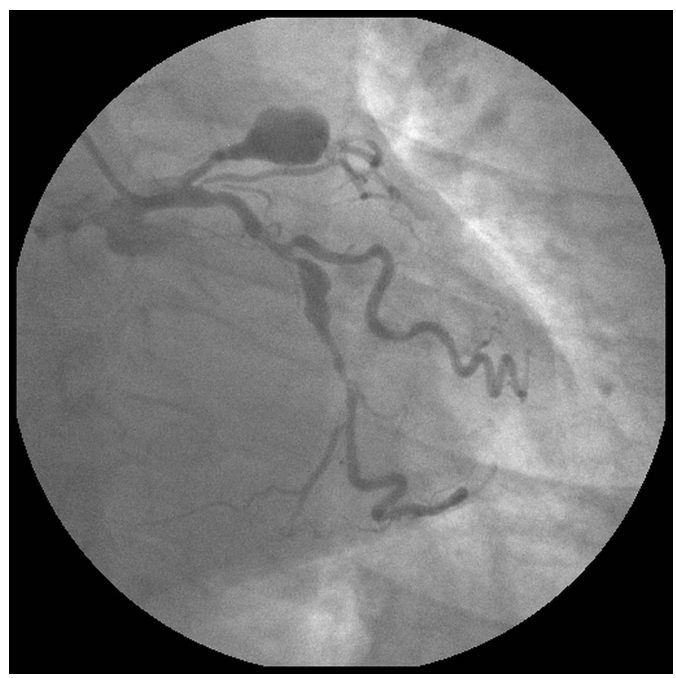

Figure 1 Right anterior oblique caudal view showing a giant aneurysm of the left anterior descending and another aneurysm of the left circumflex artery.

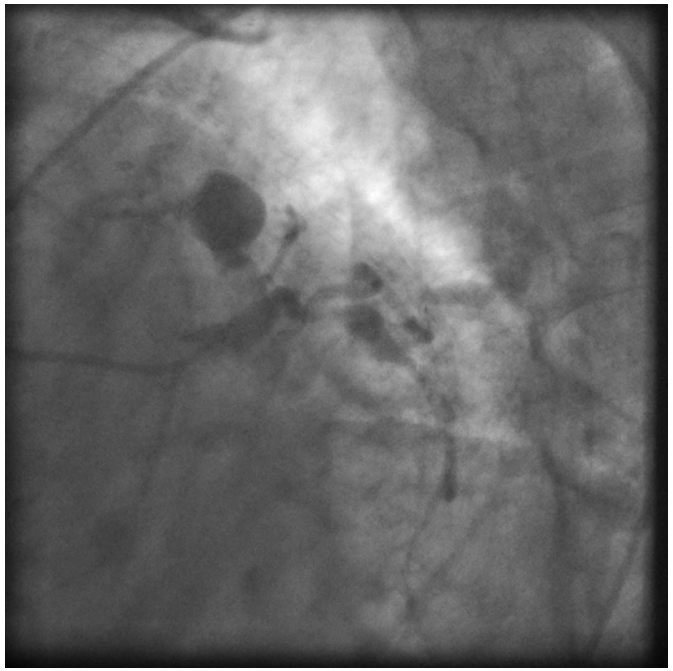

Figure 2 Left anterior oblique caudal view showing the left anterior descending and left circumflex aneurysms.

stents ${ }^{2}$ have been used in anecdotal cases with a good outcome. Giant aneurysms should be managed aggressively especially when they harbour a thrombus and also when the patient is undergoing any other cardiac surgery as in our case.

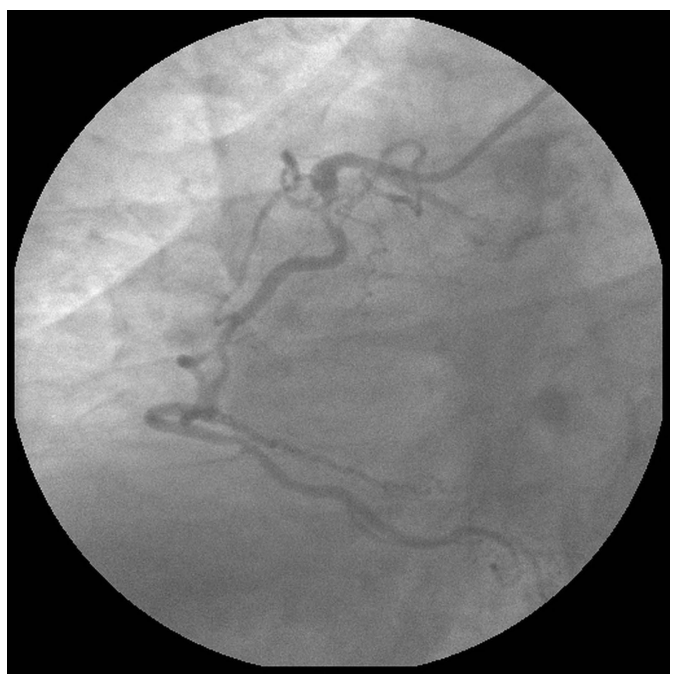

Figure 3 Left anterior oblique view showing another atherosclerotic aneurysm of the right coronary artery. 


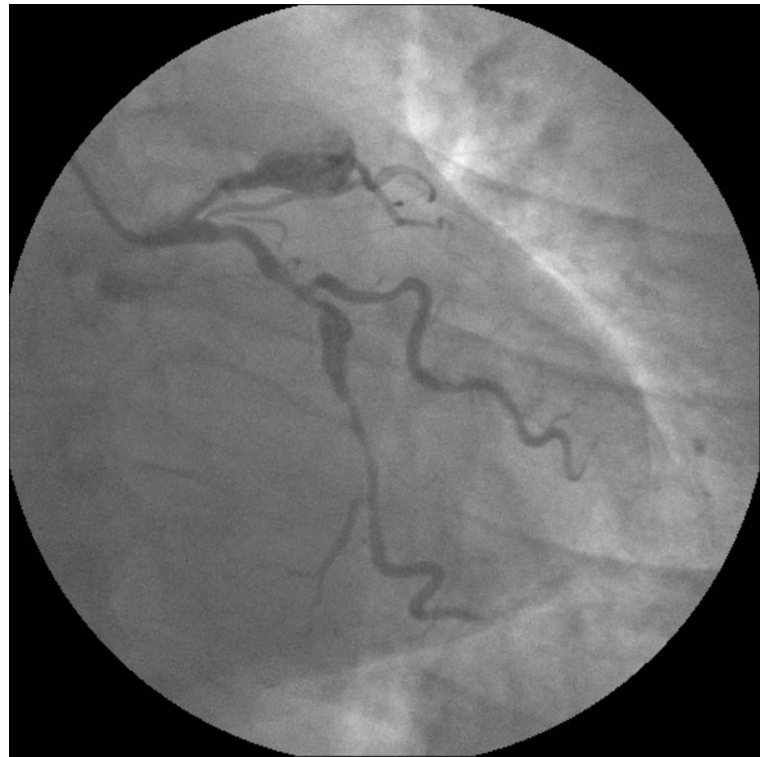

Video 1 RAO caudal view showing a giant aneurysm of the LAD and another aneurysm of the LCX artery.

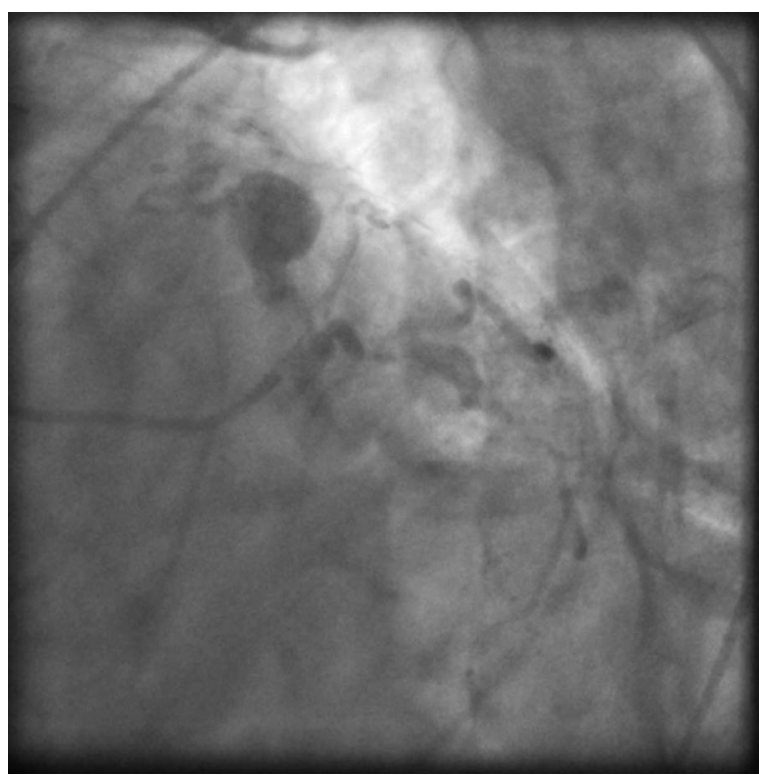

Video 2 LAO caudal view showing the LAD and LCX aneurysms.

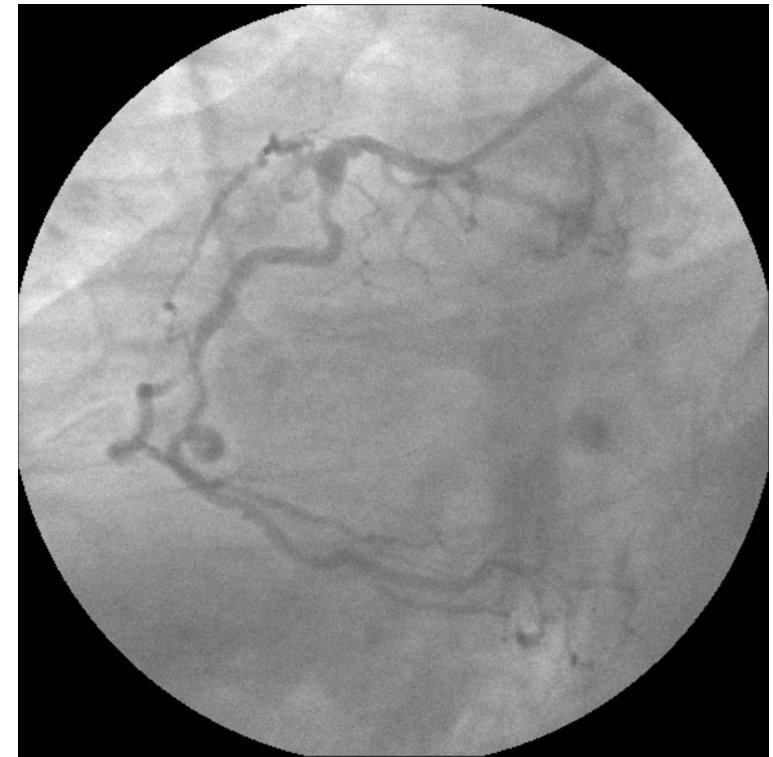

Video 3 LAO view showing another atherosclerotic aneurysm of the RCA.

\section{Learning points}

- Coronary artery aneurysms are a potential cause of thrombus formation which can lead to acute coronary syndrome and systemic embolisation even in the absence of haemodynamically significant atherosclerosis.

- There are no specific recommendations for management of coronary artery aneurysms although giant aneurysm usually needs to be treated but there is no cut-off in terms of size for intervention.

- Surgical ligation or the use of covered stents have proven successful in the management of giant coronary artery aneurysms in anecdotal cases although no particular regimen is preferred over the other.

Competing interests None.

Patient consent Obtained.

Provenance and peer review Not commissioned; externally peer reviewed.

\section{REFERENCES}

1 Li D, Wu Q, Sun L, et al. Surgical treatment of giant coronary artery aneurysm. J Thorac Cardiovasc Surg 2005;130:817-21.

2 Eshtehardi P, Cook S, Moarof I, et al. Giant coronary artery aneurysm imaging findings before and after treatment with a polytetrafluoroethylene-covered stent. Circ Cardiovasc Intervent 2008;1:85-6. 
Copyright 2014 BMJ Publishing Group. All rights reserved. For permission to reuse any of this content visit http://group.bmj.com/group/rights-licensing/permissions.

BMJ Case Report Fellows may re-use this article for personal use and teaching without any further permission.

Become a Fellow of BMJ Case Reports today and you can:

- Submit as many cases as you like

- Enjoy fast sympathetic peer review and rapid publication of accepted articles

- Access all the published articles

- Re-use any of the published material for personal use and teaching without further permission

For information on Institutional Fellowships contact consortiasales@bmjgroup.com

Visit casereports.bmj.com for more articles like this and to become a Fellow 